\title{
POLIAMINAS NA EMBRIOGÊNESE SOMÁTICA EM CENOURA (Daucus carota $\mathbf{L}$.)
}

\author{
J. SCHONS ; O. G.BRASIL ${ }^{1,2}$ \\ 1 Depto. de Química, UNESP, C.P. SO5, CEP:18618-000, Botucatu, SP. \\ 2 Bolsista CNPq
}

RESUMO: As poliaminas, putrescina (put), espermidina (spd) e espermina (spm) são amplamente distribuídas na natureza, desempenhando importante papel em vários eventos celulares. Considerando que as poliaminas estão envolvidas no processo embriogenico, torna-se importante conhecer as bases para estas alterações no metabolismo. O objetivo do presente trabalho foi observar os teores de poliaminas durante as diferentes fases da embriogênese somática da cenoura. As análises foram realizadas, através da modificação do método de Flores e Galston a cada 96 horas durante 50 dias da cultura de células em suspensão. As celulas foram obtidas a partir de calos e inoculadas em meio de Murashige \& Skoog (MS), modificado e acrescido de 0,2 mg/l de 2,4-D e 0,1 mg/ de cinetina durante os primeiros 14 dias da cultura, sendo que no restante do período permaneceram em meio MS desprovido de fitorreguladores. Os teores de poliaminas oscilaram durante todo o processo embriogênico, sendo que a putrescina foi a que apresentou maior acúmulo. Estes resultados sugerem que os níveis de espermidina e espermina são reduxidos em relação a putrescina devido a intensa utilização da spd e spm no processo de divisão e diferenciação celular, enquanto que a put parece ter apenas a função de sintetizar as outras duas amidas.

Descritores: poliaminas, embriogênese somática, cenoura, Daucus carota

\section{POLYAMINES IN SOMATIC EMBRYOGENESIS IN CARROT (Daucus carota L.)}

\begin{abstract}
The polyamines, putrescine (Put), Spermidine (Spd) and Spermine (Spm) are widely present in nature, performing an important role in various cellular events. Considering that polyamines take part of the embryogenic process, it is important to know the bases for these alterations in the metabolism. The objective of the present study was to observe the contents of polyamines during the different phases of somatic embryogenesis of carrot. Analyses were carried out, according to a modification of the method developed by Flores \& Galston every 96 hours during 50 days from the culture of cell suspensions. The cells were provided from callus and inoculated in Murashige \& Skoog (MS) medium which had been modified and added with $0.2 \mathrm{mg} / \mathrm{l}$ of 2,4-D and $0.1 \mathrm{mg} / 1$ of kinetin during the first 14 days, whereas for the other days, they were kept in MS medium deprived of phytoregulators. The contents of polyamines varied during all the embryogenic process, when putrescine showed the most accumulated. These results suggest that the levels of spermidine and spermine are reduced in relation to putrescine due to the intense use of Spd and Spm in the process of cell division and differentiation, whereas Put seems to have only the function of synthetizing the other two amines.
\end{abstract}

Key Words: polyamines, somatic embryogenesis, carrot, Daucus canota

\section{INTRODUÇÃO}

As poliaminas, putrescina (Put), espermidina (Spd) e espermina (Spm) são amplamente distribuídas na natureza, desempenhando importante papel em vários eventos celulares, tais como síntese protéica, replicação do DNA e morfogênese (TABOR \& TABOR, 1976 e BACHRACH, 1973). A biossíntese das poliaminas bem como das enzimas que regulam o seu metabolismo, têm sido estudadas em várias plantas superiores (Smith e Galston \& Kaur-Sawhney citados por KUROSAKI et al., 1992. Entretanto, o significado fisiológico e possíveis funções das poliaminas não estão suficientemente esclarecidos (KUROSAKI et al., 1992). Altos níveis de poliaminas têm sido associados com a diferenciação celular em fungos e vários sistemas de plantas (Feirer et al.; Kaur-sawhney et al. e Tabor \& Tabor, citados por TIBURCIO et al. , 1987). Assim sendo, elevados níveis de poliaminas são necessários durante a embriogênese de cenoura em cultura de tecidos (FEIRER, et al., 1984). Os níveis de poliaminas livres e conjugadas aumentaram 
drasticamente durante a diferenciação e regeneração de plantas derivadas do mesofilo de Vigna em cultura de protoplastos (KAUR-SAWHNEY et al., 1982). A formação de novas células está correlacionada com o aumento na síntese de DNA, RNA, proteínas e com a formação de poliaminas (COHEN et al., 1982). Montague et al. citados por MINOCHA et al. (1991), foram os primeiros a demonstrar que o aumento dos teores de poliaminas está correlacionado com a embriogênese somática em culturas de células de cenoura. Estes autores observaram um grande aumento dos teores de putrescina, nas culturas embriogênicas. $O$ aumento do acúmulo de putrescina $\varepsilon$ provavelmente, resultante do decréscimo de sua utilização para a biossíntese de espermidina e não ao aumento de sua produção (MINOCHA et al., 1991). Maior acúmulo de putrescina é geralmente observado em tecidos tratados com inibidores da síntese de espermidina e espermina (Hölt et al. e Pegg citados por MINOCHA et al., 1991). Estes resultados foram confirmados por MINOCHA et al. (1991), que observaram redução no acúmulo de espermidina e espermina quando usaram um inibidor de sua síntese o que levou ao conseqüente aumento nos teores de putrescina em culturas de células embriogênicas de cenoura. Estes inibidores da síntese de espermidina e espermina inibiram também a embriogênese somática em cenoura, particularmente nos estágios globular e de formação dos torpedos (MINOCHA et al., 1991). Estes resultados indicam que espermidina e espermina são elementos indispensáveis para a morfogênese de cenoura. Considerando que as poliaminas estão envolvidas no processo embriogênico de células de cenoura, torna-se importante conhecer as bases para estas alterações no metabolismo (MONTAGUE et al., 1979). $O$ objetivo do presente trabalho foi observar os teores de poliaminas durante as diferentes fases da embriogênese somática de cenoura (Daucus carota L.) em suspensão.

\section{MATERIAL E METODOS}

Os calos foram obtidos a partir de tecido radicular de cenoura, cultivar Brasília, em meio de MURASHIGE \& SKOOG (1962) modificado, e suplementado com $0,2 \mathrm{mg} / 1$ de ácido 2,4Diclorofenoxiacético $(2,4-\mathrm{D})+0,1 \mathrm{mg} / 1 \mathrm{de}$ Cinetina, conforme SCHONS (1995). Além dos fitorreguladores foram adicionadas $7 \mathrm{~g} / 1$ de ágar, $30 \mathrm{~g} / \mathrm{l}$ sacarose e o pH foi ajustado para 5,7 antes da autoclavagem. A suspensão de células foi efetuada em meio igual ao anterior, sem ágar. Inoculou-se $200 \mathrm{mg}$ de células em cada Erlenmeyer contendo $25 \mathrm{ml}$ de meio e foram mantidos sob agitação a $90 \mathrm{rpm}$ em sala de crescimento com condições de luz (2000 lux), temperatura (25 Graus Celsius) e fotoperíodo (12 horas) controlados.

Após 14 dias as células foram filtradas, lavadas e reinoculadas em meio desprovido de fitorreguladores, onde permaneceram durante $o$ processo de diferenciação celular até o qüinquagésimo dia. Para determinar os teores de poliaminas, foram utilizadas $100 \mathrm{mg}$ de matéria fresca macerada em $1 \mathrm{ml}$ de ácido perclórico a $5 \%$, banho de gelo por 1 hora seguido de centrifugação por 15 minutos a $10000 \mathrm{rpm}(9000$ g), à $4^{\circ} \mathrm{C}$. O método de dansilação e cromatografia foi adaptado de FLORES \& GALSTON (1982) e a quantificação foi feita em espectrofotometria de fluorescência.

\section{RESULTADOS E DISCUSSÃO}

Os teores de poliaminas foram analisados durante todo o processo embriogênico e os resultados podem ser observados na Figura 1.

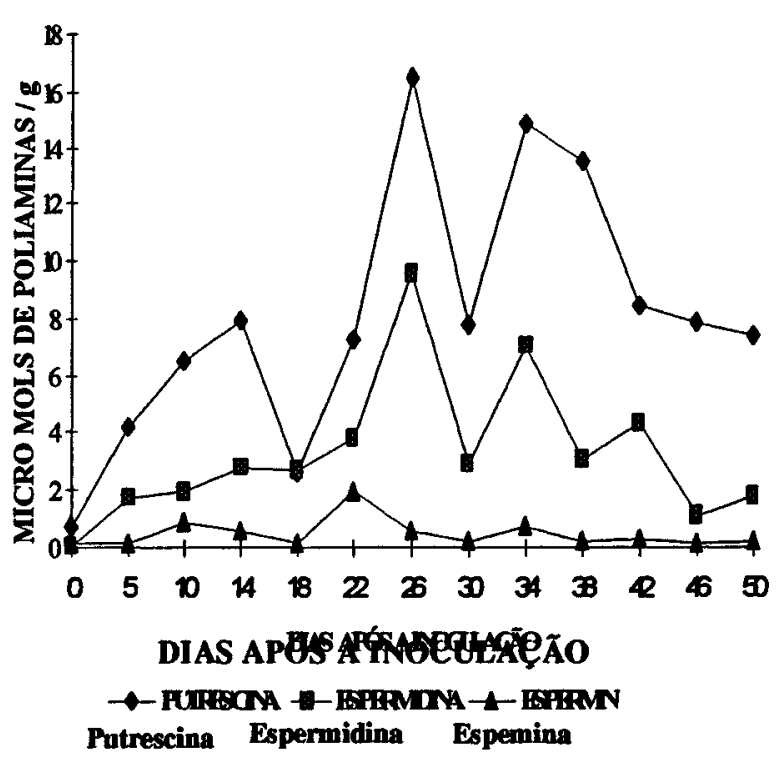

Figura 1 - Variação dos teores de poliaminas nas diferentes fases da embriogênese somática. 
O aumento nos teores de putrescina, observado no período de divisão celular (14 dias) pode representar uma alteração na síntese de poliaminas induzida, provavelmente pelo 2,4-D do meio onde putrescina $\epsilon$ precursora de espermidina e esta de espermina.A espermidina aumentou lentamente seguida da espermina que apresentou apenas um pequeno aumento. Fato semelhante foi observado por SMITH et al. (1978) em culturas em suspensão de Paul's Scarlet Rose. O aumento da putrescina na fase de divisão celular foi seguida do decréscimo observado no décimo oitavo dia, coincidindo com a fase globular, estando de acordo com o encontrado por FALLON \& PHILIPS (1988). Esta redução parece estar associada com a intensa utilização da putrescina para a síntese de espermidina , nesta primeira fase da diferenciação celular, considerando que espermidina e espermina são utilizadas no processo morfogenético propriamente dito, de acordo com MINOCHA et al. (1991). Elevado acúmulo de putrescina foi observado no vigésimo sexto dia, que caracterizou a fase de formação dos corações, seguido do aumento da espermidina.

Conforme MINOCHA et al. (1991) o aumento no acúmulo de putrescina $\epsilon$ provavelmente devido ao decréscimo da sua utilização para a biossíntese de espermidina, e não ao aumento de sua produção.

As variaçōes subsequentes, observadas nos níveis de putrescina e espermidina se assemelham aos resultados encontrados por FALLON \& PHILLIPS (1988) e o teores de espermina aos observados por KUROSAKI et al. (1992).

Resultados semelhantes com relação aos níveis de putrescina, espermidina e espermina foram também encontrados por MINOCHA et al. (1991), embora estes autores tenham observado essas variações em intervalo menor de tempo. Nossos resultados diferem dos autores citados no que se refere ao tempo de observação dos eventos de diferenciação. Estas diferenças, possivelmente estejam associadas às condições experimentais bem como ao cultivar utilizado.

As poliaminas aparecem alteradas a cada nova fase da embriogenese somática de cenoura, sendo que a putrescina $\epsilon$ a que apresenta major acúmulo. Estes resultados sugerem que os níveis de espermidina e espermina são reduzidos em relação a putrescina, devido a intensa utilização de Spd e Spm no processo de divisão e diferenciação celular.

A putrescina não parece estar envolvida diretamente no processo embriogênico, tendo como função, apenas a sintese de spd e spm.

\section{REFERENCIAS BIBLIOGRÁFICAS}

BACHRACH, U. Function of naturally occurring polyamines. New York: Academic Press, 1973.

COHEN, S. S.; ARADS, S.; HEIMER, Y. M.; MIZRAHI, Y. Participation of ornithine decarboxylase in early stages of tomato fruit development. Plant Physiology, n.70, p.540-3, 1982.

FALLON, K. M.; PHILLIPS, R. Polyamines in relation to growth in carrot cell cultures. Plant Physiology, n.88, p.224-7, 1988.

FEIRER, R. P.; MIGNON, G.; LITUAY, J. D. Arginine decarboxylase and polyamines required for embryogenesis in the wild carrot. Science, n.223, p.1433-5, 1984.

FLORES, H. E.; GALSTON. A. W. Analysis of polyamines in higher plants by high performance liquid chromatography. Plant Physiology, n.69, p.701-6, 1982.

KAUR-SAWHNEY, R.; SHIH, L. M.; GALSTON, A. $W$. Relation of polyamine biosynthesis to the initiation of spruting in potato tubers. Plant Physiology, n.69, p.411-5, 1982 .

KUROSAKI, F.; MATSUSHITA, M.; NISHI, A. Essential role of polyamines in growth of cultured carrot cells. Phytochemistry, v.31, p.3889-92, 1992.

MINOCHA, S. C.; PAPA, N. S.; JAMAL KHAN, A., SAMUELSEN, A. I. Polyamines and somatic embryogenesis in carrot. II Effects of Methylglyoxal bis (guanylhydrazone). Plant and Cell Physiology, n.32, v.3, p.395-402, 1991.

MONTAGUE, M. J.; ARMSTRONG, T. A., JAWORKI, E. G. Polyamine metabolism in embryogenic cells of (Daucus carota L.). IV. Changes in arginine decarboxylase activity. Plant Physiology, n.63, p.341$5,1979$.

SCHONS, J. Aspectos bioquímicos da embriogênese somática em cenoura (Daucus carota L.). Botucatu, 1995. 71p. Dissertação (Mestrado), Instituto de Biociências, Universidade Estadual Paulista “Julio de Mesquita Filho".

SMITH, T. A.; BEST. G. R.; ABBOTT, A..J.; CLEMENTS, E. D. Polyamines in Paul's Scarlet rose suspension cultures. Planta, n.144, p.63-8, 1978.

TABOR, C. W.; TABOR, H. 1,4 Diaminobutane (putrescina), Spermidine and Spermine. Annual Review of Biochemistry n.45, p.285, 1976.

TIBURCIO, A. F.; KAUR-SAWHNEY, R.; GALSTON, A. W. Effect of polyamine biosynthetic inhibitors on alkaloids and organogenesis in tobacco callus cultures. Plant Cell, Tissue and Organ Culture. n.9, p.111-20, 1987.

Recebido para a publicação em16.05.95

Aceito para publicação em 15.04.96 